\title{
AMHR2 Gene
}

National Cancer Institute

\section{Source}

National Cancer Institute. AMHR2 Gene. NCI Thesaurus. Code C21314.

This gene plays a role in gonadal development. 